Pinisi Business Administration Review

Vol. 2, No. 2, September 2020, Pages 51-56

ISSN (Print): 2656-6524

Homepage: http://ojs.unm.ac.id/index.php/pbar/index

\title{
The Influence of Promotion Intensity toward the Increasing of Rice Selling at Sulselbar Regional Division of Bulog Company In Makassar
}

\author{
Allamah Al Hasanah1, Muhammad Guntur², Aris Baharuddin³ \\ Business Administration Study Program, Faculty of Social Sciences, Makassar State University ${ }^{1,2,3}$ \\ E-mail: allamahalhasanah@gmail.com ${ }^{1}$
}

(Received: 28 July 2020; revised: 14 August 2020; published: 23 September 2020)

\begin{abstract}
Promotion Intensity Influence Toward The Increasing Of Rice Selling At Sulselbar Regional Division Of Bulog Company In Makassar. This research was conducted to know the promotion intensity influence toward the increasing of rice selling. Independent variable in this research was the promotion intensity and dependent variable was the increasing of rice selling at Sulselbar Regional Division of Bulog Company in Makassar. The sample in this study was Bulog partner, namely Sahabat RPK (Rumah Pangan Kita) or Our Home Food. Total number of the partners was 152 people and all of them applied Slovin sample theory. Data analysis in this research used SPSS 25 and for technique analysis, the researcher chose reliability test, validity test, classical assumption test, and inferential statistical analysis. The result of this research showed that in promotion intensity variable (X) indicated a very good trend for each indicator. Furthermore, the sales variable (y) showed a very good percentage and there was a significant influence between the intensity of promotion on the increasing of rice selling. It was proven by the result of coefficient analysis with a significance value of $0.000<0.05$ and also the coefficient of determination (R2) 0.504 or 50.4 percent which indicated that the coefficient of determination model was good and has a positive correlation.
\end{abstract}

Keywords: Promotion Intensity, Selling.

Copyright (C) 2019 Universitas Negeri Makassar. This is an open access article under the CC BY license (http://creativecommons.org/licenses/by/4.0/)

\section{INTRODUCTION}

Marketing is a social and managerial process where individuals and groups get their needs and wants by creating, offering and exchanging something of value to each other (Sudaryono, 2016). In marketing, there are several functions performed by marketing agencies that will be involved in the process of delivering goods or services from producers to consumers. marketing functions include exchange function, physical function, and intermediary function (Septiara, Maulina, \& Buwono, 2012) and in 
marketing there is also a process of planning and implementing the thinking, pricing, promotion and distribution of ideas, goods, organizational services, and events to create and maintain relationships that will satisfy the goals of individuals and organizations (Sudaryono, 2016). Family businesses need to sharpen internal focus (strategic assets) and external focus (market orientation) to improve business performance in a synergistic and sustainable manner (Henni Zainal, Parinsi, Indonesia, Hasan, \& Makassar, 2018).

Marketing mix is the scope of marketing itself according to shimizu marketing, namely 7C (Corporation, Commodity, Cost, Channel, Communication, Consumer, Circumstances) besides that, according to Kotler and Keller, the marketing mix is 4P (Product, Price, Place). , Promotion) (Aris, Syam, Haris, Jasruddin \& Akib, 2018), However, in this study focused on one variable, namely: Promotion has an effect on sales, this is in accordance with the opinion expressed by (Kotler \& Keller, 2018) that promotion is a variety of intensive tools, mostly short-term, designed to stimulate the faster and greater purchase of a particular product or service by consumers or merchants. Meanwhile, according to (Kotler \& Amstrong, 2017) Promotion is one of the tools used to inform and persuade the market about new products or services to the company through advertisements, personal selling, sales promotions, or publications.

In promotional activities there is also a Promotion Mix (Kotler \& Amstrong, 2016) is the specific blend of advertising, sales promotion, public relations, personal selling, and direct marketing tools that companies use to persuasively communicate customer value and build customer relationships. While the promotional mix is the best combination of strategies from the variables of advertising, personal selling, and promotional tools, all of which are planned to achieve the sales program (Angipora, 2002).

Sales is a management orientation that assumes that consumers will or will not purchase the company's products based on the consideration of real efforts made to arouse or encourage interest in the product (Sunyoto, 2017). Then (Kotler, 2014) As for several indicators of sales volume, namely: Achieving a certain sales volume, getting a certain profit, and supporting company growth. Based on the description of the importance of promotion to sales. So the researchers determined the object of research at the Public Company BULOG Regional Division of South Sulawesi in Makassar, which is one of the state-owned companies (State-Owned Enterprises) which oversees the development of multi-commodity food commodities besides Perum BULOG as a national institution that has the main task of planning strategies operational in public services that aim to achieve the target of procurement and supply of domestic rice.

Currently Perum BULOG consistently maintains the basic purchase price for unhulled rice, distribution of poor rice (Raskin) and management of national food stocks. related to the distribution of BULOG as an institution that is trusted by the government to implement policies in an effort to distribute rice to the public so that this can touch all market segmentations that exist physically as well as economically. 
Allamah Al Hasanah et.all; Pengaruh Insentitas Promosi... $\mid 53$

BULOG activities in improving service quality are proven through marketing activities related to the introduction of products sold / offered, product design, product advertising, product distribution to consumers to product promotion activities that are carried out continuously, so that the company is able to understand consumers as best as possible so that it affects consumer purchasing power. the product offered.

Perum BULOG as a national institution aimed at ensuring food availability, proper promotion is needed because the promotional activities carried out by Perum BULOG have only focused on certain market segments and besides that, the lack of public understanding regarding other products / commodities Perum BULOG will have an effect on company sales. which will hinder the company's growth. That is why it is necessary to conduct research on the effect of the intensity of promotion in relation to increased rice sales. The purpose of this study was to examine the effect of the promotional intensity variable on rice sales of the general company BULOG, the regional division of Sulselbar in Makassar.

\section{RESEARC METHOD}

The design used in this research is quantitative research, which is to test hypotheses in accordance with the formulation of the problem under study so that it can be seen that there is or does not have a significant impact between the intensity of promotion on the increase in rice sales of the general company BULOG Regional Division of South Sulawesi in Makassar. The target population in this study were BULOG's friends, namely RPK (Rumah Pangan Kita), amounting to 505 partners spread across the South Sulawesi region, because this research was conducted in the city of Makassar. The number of RPKs scattered in the city of Makassar is 243. Thus, the sample determination is used using the Slovin formula with a significance level of $5 \%$. Then obtained a total sample of 152 RPK partners. The types of data used in this study are quantitative data and qualitative data. Quantitative data is data obtained from distributing research questionnaires to respondents in the form of numbers which are then re-analyzed. Qualitative data is data obtained from Perum BULOG Divre Sulselbar in Makassar in the form of information both orally and in writing, which acts as supporting data in the preparation of writing. Meanwhile, the data sources used are primary and secondary data. Primary data is obtained from respondents' answers to the question items posed to respondents in the research questionnaire. Secondary data, namely data obtained from documents at the Perum BULOG Regional Division of Sulselbar in Makassar which are related to this research.

Data collection techniques, namely by means of field research and literature. Field research by searching for and obtaining data from RPK partners of Perum BULOG who were respondents in this study and seeking and obtaining data from Perum BULOG, Regional Division of South Sulawesi in Makassar. The methods used are observation, interviews, research questionnaires, and documentation. Observation, 
make direct observations and study matters related to direct research at Perum BULOG Makassar Regional Division of Sulselbar. Interviewing, conducting interviews with the commercial and sales department who have authority in relation to the problem being researched. The questionnaire asks questions that have been prepared in writing by distributing questionnaires and accompanied by alternative answers that will be given by the respondent. Library research, obtaining data by reading and studying books or literature that is related to the field of marketing related to the object of research.

\section{RESEARCH RESULTS AND DISCUSSION}

Respondents' answer data regarding the intensity of promotion, so for the first indicator of advertising, the average respondent gave a fairly agreeable answer, namely with a percentage of $(78.38 \%)$, the second indicator was sales promotion with the average respondent giving very agreeable answers, namely with a percentage of ( $85.35 \%$ ), the third indicator of public relations with the average respondent giving an agreed answer with a percentage of $(85.04 \%)$, the fourth indicator is direct marketing with the average respondent giving an agreed answer, namely with a percentage of $(84.07 \%)$, the indicator Fifth, personal sales with an average respondent answered strongly agree with a percentage of $(87.06 \%)$. Thus, it can be concluded that the intensity of promotion at Perum BULOG Regional Division of Sulselbar has been going very well.

The percentage of respondents' answers regarding the increase in sales, as for the first indicator, namely the average sales volume, the respondents gave a very agreeable answer, namely with a percentage of $(86.84 \%)$, the second indicator achieved a certain profit the average respondent gave an answer strongly agree with a percentage of 86 , 65). The third indicator is company growth with the average respondent giving agreeable answers with a percentage of $(82.89 \%)$. Thus, it can be concluded that sales at BULOG have been going very well.

The results of this study indicate that the regression coefficient analysis results for the intensity of promotion are 0.504 and have a p-value of 0.003 . Therefore, it can be concluded that the intensity of promotion has a positive and significant effect on the increase in rice sales at the Perm BULOG Regional Division of Sulselbar in Makassar. Promotion problem is one of the factors that influence sales. Meanwhile, from the results of research conducted by researchers, especially at Perum BULOG Regional Division of Sulselbar in Makasaar. It was found that promotional activities at Perum BULOG Regional Division of Sulselbar in Makasaar always carry out intensive promotions, especially in direct marketing activities and personal sales which have a very good percentage.

Then from the results of the partial testing conducted, it shows that the intensity of the promotion has a significant effect on increasing sales. It can be said that the increase (decrease) in the intensity of promotions carried out at Perum BULOG 
Allamah Al Hasanah et.all; Pengaruh Insentitas Promosi... $\mid 55$

Regional Division of Sulselbar in Makasaar will significantly increase rice sales, especially at Perum BULOG Regional Division of Sulselbar in Makasaar. Promotion intensity problem is one of the aspects that affect sales at Perum BULOG Regional Division of Sulselbar in Makassar. The findings were that in order to increase rice sales, a series of intense promotional activities was carried out at the Regional Office of the Regional Office of BULOG in South Sulawesi in Makasaar. Namely by doing advertising, direct marketing, personal selling, public relations and sales promotion. Then one of the advantages possessed by Perum BULOG Regional Division of Sulsebar, namely HR (Human Resources) spread across various regions and supported by warehouse infrastructure as a means of promotion and other efforts made by Perum BULOG Regional Division of Sulsebar in supporting increased sales is such as low-cost market activities and car free day, distributing brochures and always providing services to customers. This shows that the intensity of the promotion can affect the increase in sales.

\section{CONCLUSION}

Based on the results of data analysis and research, several conclusions will be presented, namely based on the results of the regression coefficient, it is obtained that the promotion intensity is 0.504 and has a p-value of 0.003 . So it can be concluded that the intensity of promotion has a positive and significant effect on increasing rice sales at the Regional Office of BULOG for the South Sulawesi Regional Division in Makassar, it is recommended that promotional activities be carried out using digital-based promotional media or online massively to customers because it will be more effective and efficient than using In addition to conventional media, it is important to increase company sales to ensure that the implementation of work is in accordance with the standards that have been set in planning. As well as other efforts, namely establishing good relations with the internal components of the company and maintaining company integrity.

\section{BIBLIOGRAPHY}

Amstrong, Kotler. 2001. Prinsip-Prinsip Pemasaran. Jakarta: Erlangga.

Angipora P. 2002. Dasar-Dasar Pemasaran. Jakarta: Rajawali Pers.

Aras, M., Syam, H., Haris, H., Jasruddin, M., \& Akib, H. 2018. The Analysis of Mix Marketing System Toward The Performance of Convection Business in Makassar. Atlantis Press.

Batubara, Hidayat. 2016. "No Title." Pengaruh Penetapan Harga dan Promosi terhadap peningkatan penjualan Tiket pada PSA Mihin Lanka Airlines. Jurnal Ilham 4(1).

Budianto. 2015. Manajemen Pemasaran. Yogyakarta: Penerbit Ombak. 
56 Pinisi Business Administration Review

Volume 2 Number 2, September 2020. Pages 51-56

Dimitri Alamkan. 2019. "Structured Resources in Web Development, Marketing and Enterpreneurship." https://www.orgamizer.com/marketing/models.

Henni Zainal, U. I. T., Parinsi, W. K., Indonesia, S. P., Hasan, M., \& Makassar, U. N. (2018). The Influence Of Strategic Assets And Market Orientation To The Performance Of Family Business In Makassar City , Indonesia, 17(6), 1-9.

Sudaryono. 2016. Manajemen Pemasaran (Teori Dan Implementasi). Yogyakarta: Penerbit Andi.

Hidayat, Fandi P. 2012. "Pengaruh Implementasi Bauran Pemasaran Jasa Terhadap Keputusan Wisatawan Mengunjungi Objek Wisata Pulau Pasumpahan." doi:10.31219/osf.io/bf8mz.

Kotler, Keller. 2018. Manajemen Pemasaran. Jilid II. Jakarta: PT.Indeks.

Kotler P. 1993. Manajemen Pemasaran. Jilid II. Jakarta: Lembaga Penerbit Fakultas Ekonomi Universitas Indonesia.

Listianto L, Pradhanawati, dkk. 2014. "Pengaruh Promosi, Intensitas Persaingan Dan Kebijakan Produk Terhadap Kinerja Pemasaran Bandeng Presto Pada Sentra Usaha Kelurahan Tambakrejo Semarang." Jurnal Ilmu Administrasi Bisnis 3(3).

Lontoh. 2016. "Analisis Pengaruh Bauran Promosi Terhadap Keputusan Pembelian Mobil Toyota Pada PT. Hasjrat Abadi Manado Cabang Tandean." Jurnal Emba $1(3)$.

Mandey B. 2013. "Promosi, Distribusi , Harga Pengaruhnya Terhadap Keputusan Pembelian Rokok Promild." Jurnal Emba 1(4).

Mukarommah, Maro'ah dkk. 2018. "Implementasi Strategi Bauran Pemasaran Dalam Meningkatkan Volume Penjualan Toko Baju Senam Seragam.Com.” Jurnal Eksekutif 15(2).

Nugeraha Z.2013. "Pengaruh Promosi Dalam Meningkatkan Penjualan Pada Pt.Seratus Sembilan Saudagar Makassar." Universitas islam negeri alauddin makassar

Pradiani T. 2017. "Pengaruh Pemasaran Digital Marketing Terhadap Peningkatan Volume Penjualan Hasil Industri Rumahan." Jurnal Jibeka 11(2).

Rangkuti, Freddy. 2009. Strategi Promosi Yang Kreatif Dan Analisis Kasus Integrated Marketing Communication. Jakarta: PT. Gramedia psutaka utama.

Rositasari. 2017. "Pengaruh Promosi Terhadap Keputusan Pembelian Smartphone Samsung Pada Mahasiswa Fakultas Ekonomi Universitas Negeri Makassar.” Universitas negeri makassar.

Ruslan. 2017. "Pengaruh Saluran Distribusi Terhadap Volume Penjualan Pada PT. Semen Tonasa Di Kabupaten Pangkep." Universitas negeri makassar.

Sudaryono. 2016. Manajemen Pemasaran (Teori Dan Implementasi). Yogyakarta: Penerbit Andi. 